\title{
The comparison of pleurodesis effects of iodopovidone at different concentrations and magnesium silicate: An experimental study
}

\author{
lodopovidonun farklı konsantrasyonları ile magnezyum silikatın plörodez etkilerinin karşılaştırıması: \\ Deneysel çallşma
}

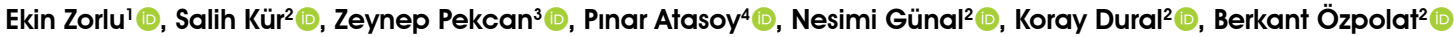 \\ Institution where the research was done: \\ Kirikkale University Faculty of Medicine, Kirkkale, Turkey \\ Author Affiliations: \\ 'Department of Thoracic Surgery, University of Health Sciences, Izmir Bozyaka Training and Research Hospital, Izmir, Turkey \\ ${ }^{2}$ Department of Thoracic Surgery, Kirkkale University Faculty of Medicine, Kirkkkale, Turkey \\ ${ }^{3}$ Department of Surgery, Krrkkale University Faculty of Veterinary Medicine, Kirkkale, Turkey \\ ${ }^{4}$ Department of Pathology, Koç University Faculty of Medicine, Istanbul, Turkey
}

\begin{abstract}
Background: This experimental study aims to investigate the pleurodesis effects of iodopovidone at different concentrations (2\% and $4 \%)$ and sterile talc in a rat model.

Methods: Forty male Wistar Albino rats were randomly divided into four equal groups including 10 rats in each group. Groups 1,2, and 3 were designed as the study, and Group 4 as the control group. In Group 1, $4 \mathrm{~g}$ sterile talc was given in the slurry form at $20 \mathrm{~mL} 0.9 \%$ saline solution, in Group 2 and Group 3 10\% iodopovidone solution were given at $4 \%$ and $2 \%$ concentrations, respectively, and in Group $4,0.9 \%$ saline was only administrated as $3 \mathrm{~mL}$ into the pleural space. All rats were sacrificed on Day 30 and evaluated for macroscopic and microscopic examination. Microscopic evaluation was performed for alveolar collapse, alveolar hemorrhage, alveolar infiltration and fibrosis. Brain, liver, and kidney tissues were also examined.
\end{abstract}

Results: Iodopovidone macroscopically caused a significant adhesion similar to sterile talc at a concentration of $4 \%$. The pleurodesis effect of iodopovidone at a concentration of $4 \%$ was significantly similar to talc, when microscopic parameters were evaluated. Granulomas due to sterile talc were observed in the opposite hemithorax. Brain, liver, and kidney examinations revealed no systemic distribution for both agents.

Conclusion: Iodopovidone is a powerful alternative to sterile talc with its easy accessibility and low cost. In this study, $4 \%$ iodopovidone was found to provide effective and safe pleurodesis in rats. We believe that the use of this concentration in clinical studies would provide more effective results.

Keywords: Chemical pleurodesis, iodopovidone, malignant pleural effusion, sterile talc.
$\ddot{O} Z$

Amaç: $\mathrm{Bu}$ deneysel çalışmada bir sıçan modelinde iodopovidonun farklı konsantrasyonlarının (\%2 ve \%4) ve steril talkın plörodez etkileri araştırıldı.

Çalışma planı: Kırk erkek Wistar Albino sıçan, her grupta 10 sıçan olacak şekilde rastgele dört eşit gruba ayrıldı. Grup 1, 2, 3 çalışma grubu ve Grup 4 kontrol grubu olarak belirlendi. Grup 1'e $4 \mathrm{~g}$ steril talk $20 \mathrm{~mL} \% 0.9$ serum fizyolojik ile bulamaç haline getirilerek verildi; Grup 2 ve Grup 3'e \%10 iodopovidon solüsyonu sırasıyla $\% 4$ ve $\% 2$ konsantrasyonlarında verildi ve Grup 4'e \%0.9 serum fizyolojik 3'er $\mathrm{mL}$ olacak şekilde plevral aralığa uygulandı. Siçanlar 30. günde sakrifiye edilerek, makroskobik ve mikroskobik inceleme yapılmak üzere değerlendirildi. Mikroskobik değerlendirme alveoler kollaps, alveoler hemoraji, alveoler infiltrasyon ve fibrozis açısından yapıldı. Beyin, karaciğer ve böbrek dokuları da incelendi.

Bulgular: İodopovidon \%4 konsantrasyonda makroskobik olarak steril talka benzer şekilde önemli yapışıklığa neden oldu. İodopovidonun $\% 4$ konsantrasyonda plörodez etkisinin de, mikroskobik parametreler değerlendirildiğinde, anlamlı şekilde talka benzer olduğu görüldü. Karşı hemitoraksta steril talka bağlı granülomlar izlendi. Beyin, karaciğer ve böbrek incelemelerinde her iki ajanın da sistemik yayılımı görülmedi.

Sonuç: İodopovidon kolay ulaşılabilir olması ve maliyetinin düşük olması nedeniyle steril talka güçlü bir alternatiftir. Bu çalışmada, \% 4'lük iodopovidonun sıçanlarda etkili ve güvenli bir plörodez sağladı̆̆ görüldü. Klinik çalışmalarda bu konsantrasyonun kullanımının daha etkin sonuçlar sağlayacağını düşünmekteyiz.

Anahtar sözcükler: Kimyasal plörodez, iodopovidon, malign plevral efüzyon, steril talk.

Received: September 01, 2020 Accepted: October 16, 2020 Published online: October 20, 2021

Correspondence: Ekin Zorlu, MD. SBÜ İzmir Bozyaka Eğitim ve Araştırma Hastanesi Göğüs Cerrahisi Kliniği, 35170 Karabağlar, İzmir, Türkiye. Tel: +90232 - 2505050 e-mail: ekinzorlu@hotmail.com 
One of the methods used in the treatment of malignant pleural effusion (MPE) is chemical pleurodesis performed for the adhesion of the pleural leaves and obliteration of the cavity by giving a sclerosing agent to the pleural cavity. ${ }^{[1]}$ Although many substances have been attempted over the years, sterile talc is the most common and effective one. ${ }^{[2-4]}$ However, it has serious side effects such as systemic distribution and, rarely, acute respiratory distress syndrome (ARDS). Systemic distribution has been attempted to be prevented with certain particle sizes, but this increases its cost. ${ }^{[5,6]}$

Iodopovidone has been used in patients with MPE and pneumothorax as a pleurodesis agent owing to its strong cytotoxic, oxidative effect, it initiates the inflammatory response on the pleural surfaces; however, a consensus upon its dosage has not been reached, yet. ${ }^{[1,7,8]}$

In this experimental study, we aimed to investigate the pleurodesis effects of iodopovidone at different concentrations and sterile talc in a rat model.

\section{MATERIALS AND METHODS}

\section{Animals}

Forty male Wistar Albino rats weighing between 280 and $320 \mathrm{~g}$ and aged seven to nine weeks were used in the experimental study. All animals were cared for in accordance with the European Convention on Animal Care. The study was approved by the Animal Ethics Committee of Kirıkkale University Faculty of Medicine (No: 2017: 17/18).

\section{Study design and chemicals}

The rats were divided into four groups including 10 rats in each group. Groups 1,2,3 were designed as the study and Group 4 as the control group. In Group 1, $4 \mathrm{~g}$ sterile talc (Steritalc R Novatech SA, La Choix, France) was given in the slurry form at $20 \mathrm{~mL} 0.9 \%$ saline solution. In Group 2 and Group 3, 10\% iodopovidone (Poviexin R Ekin Medical, Ankara, Turkey) solution was given as $4 \%$ and $2 \%$ concentrations, respectively. In Group 4, 0.9\% saline solution (Polifarma Ilaç San. Tic. A.Ş. Istanbul, Turkey) was only administrated as $3 \mathrm{~mL}$ into the pleural spaces.

Xylazine $5 \mathrm{mg} / \mathrm{kg}$ (Intermed Pharma \& Medical Supplies Inc., Cebu City, Philippines) and ketamine hydrochloride $50 \mathrm{mg} / \mathrm{kg}$ (Interhas Animal Health, Ankara, Turkey) was used for the general anesthesia procedure.

\section{Surgical procedure}

The rats were surgically treated after quarantined for 15 days in the animal laboratory. The skin, subcutaneous, and muscular tissues were passed through the right hemithorax laterally with a 5-mm incision, until the ribs and intercostal muscles were seen on the chest wall. A 22-gauge polytetrafluoroethylene catheter was inserted into the pleural cavity and the solutions were injected into the thoracic cavity. The air in the intrapleural space was evacuated with the aid of a three-way tap, and the catheter was drawn. The incision was closed with atraumatic silk sutures. Rotations were made in all directions to fully spread the solution injected into the rats on the pleural surfaces. The control group was also injected with $3 \mathrm{~mL}$ saline solution with the same method.

Chest X-ray was taken in all rats and all rats were radiologically checked for pneumothorax. The rats were checked daily for 30 days. Mortality was not observed in any group. After 30 days, sacrification with spinal shock was performed under high-dose general anesthesia. To be able to visualize and evaluate the

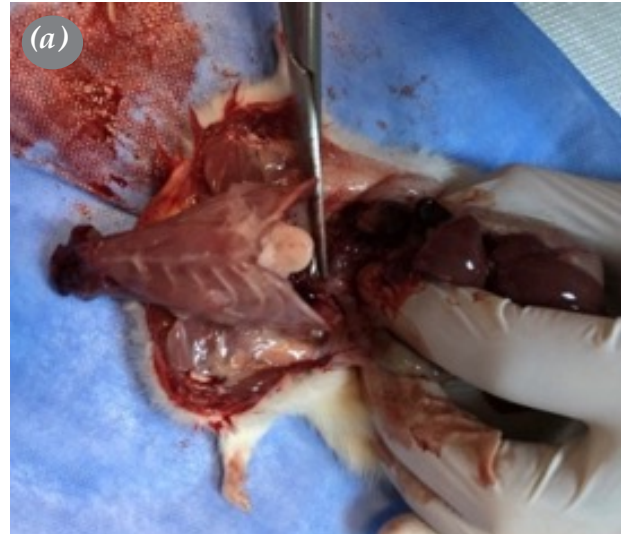

Figure 1. En-bloc removal of the thorax.

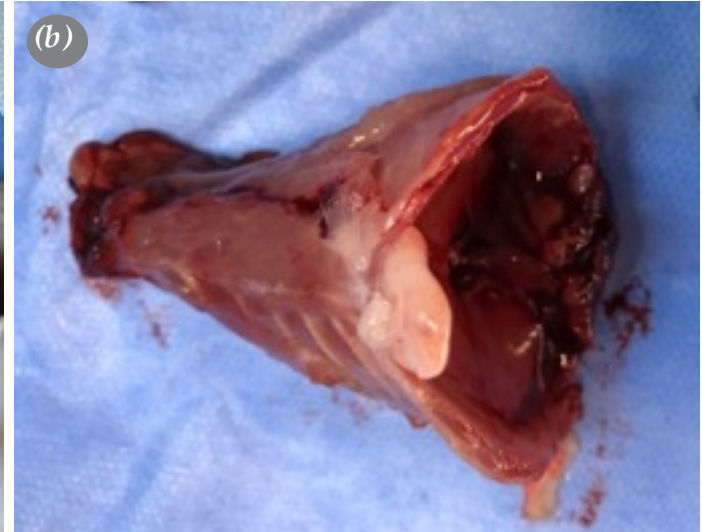


pleural surfaces thoroughly, the thorax was removed en-bloc and specimens were collected for pathological examination (Figure 1).

\section{Histopathological analysis}

In the pathology laboratory, macroscopic scoring of pleurodesis was performed by a blind researcher, using the method described by Hurewitz et al. ${ }^{[9]}$ According to this scoring system, Grade 0 refers to normal pleura, Grade 1 to small scattered adhesions, Grade 2 to generalized diffuse adhesions, and Grade 3 to complete obliteration of the pleural cavity.

Lungs, pleural cavities, mediastinal structures, and diaphragm were placed in the $10 \%$ formaldehyde solution. In addition, brain, liver and kidney tissue were also placed in formalin solution and fixed for pathological evaluation.

The chest wall, pleura, and lung-containing areas were prepared in the anteroposterior plane to be embedded in paraffin. After the paraffin sections were taken, the tissues were stained with hematoxylin and eosin (H-E) for microscopic evaluation. The microscopic evaluation was made by a blind pathologist to the groups using the method described by Vargas et al., ${ }^{[10]}$ and scoring of alveolar collapse (the collapse of the area necessary for gas exchange), alveolar hemorrhage (blood collection in the alveolar space), fibrosis (inflammatory cells and fibroblast accumulation with neovascularization), cellular infiltrate (total number of cells in alveoli) were performed as Grade 0; no findings, Grade 1; very little, Grade 2; less, Grade 3; medium, and Grade 4; severe. Intrapleural adhesions and cellularity degree of visceral pleura and neovascularity were examined and scored by the system used by Hurewitz et al. ${ }^{[9]}$ as Grade 0; no findings, Grade 1; less, Grade 2; medium, and Grade 3; severe. ${ }^{[9]}$

Diaphragm, brain and kidney tissues were stained with $\mathrm{H}-\mathrm{E}$ for microscopic evaluation after taking paraffin sections. They were examined microscopically for the granulomas and talc particles.

\section{Statistical analysis}

Statistical analysis was performed using the IBM SPSS version 20.0 software (IBM Corp., Armonk,

Table 1. Test of normality ${ }^{\mathrm{b}, \mathrm{c}}$

\begin{tabular}{|c|c|c|c|c|c|c|c|}
\hline & \multirow[b]{2}{*}{ Group } & \multicolumn{3}{|c|}{ Kolmogorov-Smirnov ${ }^{\mathrm{a}}$} & \multicolumn{3}{|c|}{ Shapiro-Wilk } \\
\hline & & Statistic & $\mathrm{df}$ & $\begin{array}{l}\text { Significance } \\
\text { (p) }\end{array}$ & Statistic & $\mathrm{df}$ & $\begin{array}{l}\text { Significance } \\
\text { (p) }\end{array}$ \\
\hline \multirow{4}{*}{ Alveolar collapse } & G1Talc & 0.381 & 10 & 0.001 & 0.640 & 10 & 0.001 \\
\hline & $\mathrm{G} 2 \% 4$ & 0.300 & 10 & 0.011 & 0.815 & 10 & 0.022 \\
\hline & G3 \%2 & 0.381 & 10 & 0.001 & 0.640 & 10 & 0.001 \\
\hline & G4K & 0.524 & 10 & 0.001 & 0.366 & 10 & 0.001 \\
\hline \multirow{4}{*}{ Cellular } & G1Talc & 0.245 & 10 & 0.091 & 0.820 & 10 & 0.025 \\
\hline & $\mathrm{G} 3 \% 2$ & 0.381 & 10 & 0.001 & 0.640 & 10 & 0.001 \\
\hline & $\mathrm{G} 3 \% 2$ & 0.433 & 10 & 0.001 & 0.594 & 10 & 0.001 \\
\hline & G4K & 0.524 & 10 & 0.001 & 0.366 & 10 & 0.001 \\
\hline \multirow{4}{*}{ Alveolar hemorrhage } & G1Talc & 0.245 & 10 & 0.091 & 0.820 & 10 & 0.025 \\
\hline & $\mathrm{G} 2 \% 4$ & 0.433 & 10 & 0.001 & 0.594 & 10 & 0.001 \\
\hline & $\mathrm{G} 3 \% 2$ & 0.482 & 10 & 0.001 & 0.509 & 10 & 0.001 \\
\hline & G4K & 0.524 & 10 & 0.001 & 0.366 & 10 & 0.001 \\
\hline \multirow{3}{*}{ Fibrosis } & G1Talc & 0.300 & 10 & 0.011 & 0.815 & 10 & 0.022 \\
\hline & $\mathrm{G} 2 \% 4$ & 0.381 & 10 & 0.001 & 0.640 & 10 & 0.001 \\
\hline & $\mathrm{G} 3 \% 2$ & 0.524 & 10 & 0.001 & 0.366 & 10 & 0.001 \\
\hline \multirow{3}{*}{ Macroscopy } & G1Talc & 0.433 & 10 & 0.001 & 0.594 & 10 & 0.001 \\
\hline & $\mathrm{G} 2 \% 4$ & 0.381 & 10 & 0.001 & 0.640 & 10 & 0.001 \\
\hline & G3 $\% 2$ & 0.329 & 10 & 0.003 & 0.655 & 10 & 0.001 \\
\hline
\end{tabular}

a: Lilliefors Significance correction; b: Fibrosis is constant when Group= G4K. It has been omitted; c: Macroscopy is constant when Group= G4K. It has been omitted. 
Table 2. Classification of microscopic and macroscopic scores

\begin{tabular}{|c|c|c|c|}
\hline & Group & $\mathrm{n}$ & Mean rank \\
\hline \multirow{5}{*}{ Alveolar collapse } & G1Talc & 10 & 31.90 \\
\hline & $\mathrm{G} 2 \% 4$ & 10 & 24.10 \\
\hline & G3 \%2 & 10 & 15.40 \\
\hline & G4K & 10 & 10.60 \\
\hline & Total & 40 & \\
\hline \multirow{5}{*}{ Cellular infiltrate } & G1Talc & 10 & 30.10 \\
\hline & G2 \%4 & 10 & 19.70 \\
\hline & $\mathrm{G} 3 \% 2$ & 10 & 17.90 \\
\hline & G4K & 10 & 14.30 \\
\hline & Total & 40 & \\
\hline \multirow{5}{*}{ Alveolar hemorrhage } & G1Talc & 10 & 29.10 \\
\hline & $\mathrm{G} 2 \% 4$ & 10 & 23.75 \\
\hline & $\mathrm{G} 3 \% 2$ & 10 & 15.00 \\
\hline & G4K & 10 & 14.15 \\
\hline & Total & 40 & \\
\hline \multirow{5}{*}{ Fibrosis } & G1Talc & 10 & 32.10 \\
\hline & G2 \%4 & 10 & 28.90 \\
\hline & G3 $\% 2$ & 10 & 11.00 \\
\hline & G4K & 10 & 10.00 \\
\hline & Total & 40 & \\
\hline \multirow{5}{*}{ Macroscopy } & G1Talc & 10 & 32.00 \\
\hline & $\mathrm{G} 2 \% 4$ & 10 & 29.00 \\
\hline & G3 \%2 & 10 & 13.00 \\
\hline & G4K & 10 & 8.00 \\
\hline & Total & 40 & \\
\hline
\end{tabular}

NY, USA). Descriptive data were expressed in mean \pm standard error (SE) or number and frequency, where applicable. The Kolmogorov-Smirnov and ShapiroWilk tests were used to examine whether the data were suitable for normal distribution. The Kruskal-Wallis test was used to analyze variables that did not meet normal distribution assumption. A $p$ value of $<0.05$ was considered statistically significant.

\section{RESULTS}

Table 1 shows the results of the test of normality for all variables at $p>0.05$. The grading of microscopic and macroscopic scores and statistical analysis results are shown in Tables 2 and 3, respectively. All rats were checked with X-ray and no pneumothorax was observed (Figure 2).

\section{Macroscopic analysis}

Adhesions were evaluated after exploring the chests of rats. No macroscopic adhesion was detected in the control group. No adhesion was detected on contralateral pleural surfaces in any of the groups.

The pairwise comparisons of the groups and the results of the auditory analysis are shown in Table 3. Severe adhesions which were significant in talc and $4 \%$ iodopovidone group are shown in Figure $3(\mathrm{p}<0.05)$. In Figure 4, granulomas are shown on the same side and on the contralateral side of the visceral pleura in the talc group.

\section{Microscopic analysis}

\section{Alveolar collapse}

The analysis results revealed that alveolar collapse scores significantly differed among four groups $\left(\chi^{2}(3), \mathrm{p}<0.05\right)$. The pairwise comparisons of the groups and the results of the auditory analysis are shown in Table 4. Figure 5a shows the alveolar collapse findings of the rat in the talc group. Accordingly, the alveolar cavities were completely closed on the right side of the figure and had a solid appearance (H-E, $\times 40)$. Figure $5 \mathrm{~b}$ shows the alveolar collapse view of the rat in the $4 \%$ iodopovidone group. According to that alveolar collapse is observed minimally (H-E, $\times 40)$.

Table 3. Binary comparisons of groups macroscopically

\begin{tabular}{lccccc}
\hline Sample 1-Sample 2 & Test statistic & SE & Standard test statistic & Significance (p) & Adjacent significance (p) \\
\hline G4K-3 \%2 & 5,000 & 4,997 & 1,001 & 0.317 & 1,000 \\
G4K-2 \%4 & 21,000 & 4,997 & 4,202 & 0.001 & 0.001 \\
G4K-1Talk & 24,000 & 4,997 & 4,802 & 0.001 & 0.001 \\
G3 \%2-G2 \%4 & 16,000 & 4,997 & 3,202 & 0.001 & 0.008 \\
G3 \%2-G1Talk & 19,000 & 4,997 & 3,802 & 0.001 & 0.001 \\
G2 \%4-G1Talk & 3,000 & 4,997 & 0,600 & 0.548 & 1,000 \\
\hline
\end{tabular}

SE: Standard error; Each row tests the null hypothesis that the Sample 1 and Sample 2 distributions are the same asymptotic significance (2-sided tests) are displayed. The significance level is 05 . 


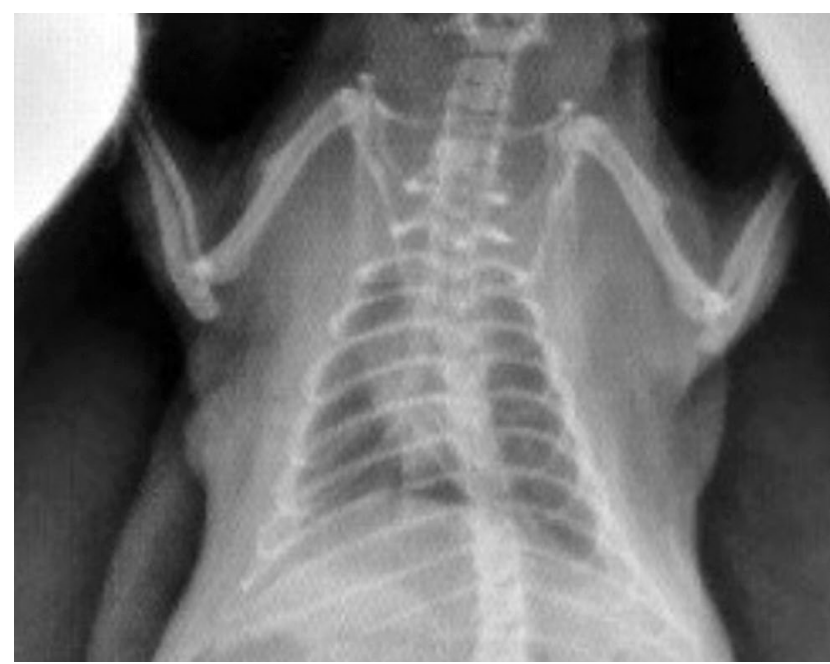

Figure 2. Anteroposterior X-ray view of a rat showing both lungs expanded.
Multiple comparisons and all pairwise tests were used to determine which groups differed from each other. Accordingly, the differences between the groups of G1Talc and G3 2\% and between the G1Talc and $\mathrm{G} 4 \mathrm{~K}$ and between the $\mathrm{G} 24 \%$ and $\mathrm{G} 4 \mathrm{~K}$ were statistically significant.

\section{Cellular infiltrate}

The cellular infiltrate scores significantly differed among the groups $\left(\chi^{2}(3), p<0.05\right)$. According to the cellular infiltrate factor, the differences between the groups G1Talc and G3 2\% and between the groups of G1Talc and G4K were statistically significant. The pairwise comparisons of the groups and the results of the auditory analysis are shown in Table 5. Figure 6a shows the inflammatory cell infiltration of the rats in the talc group. Accordingly, dense mixed cellular
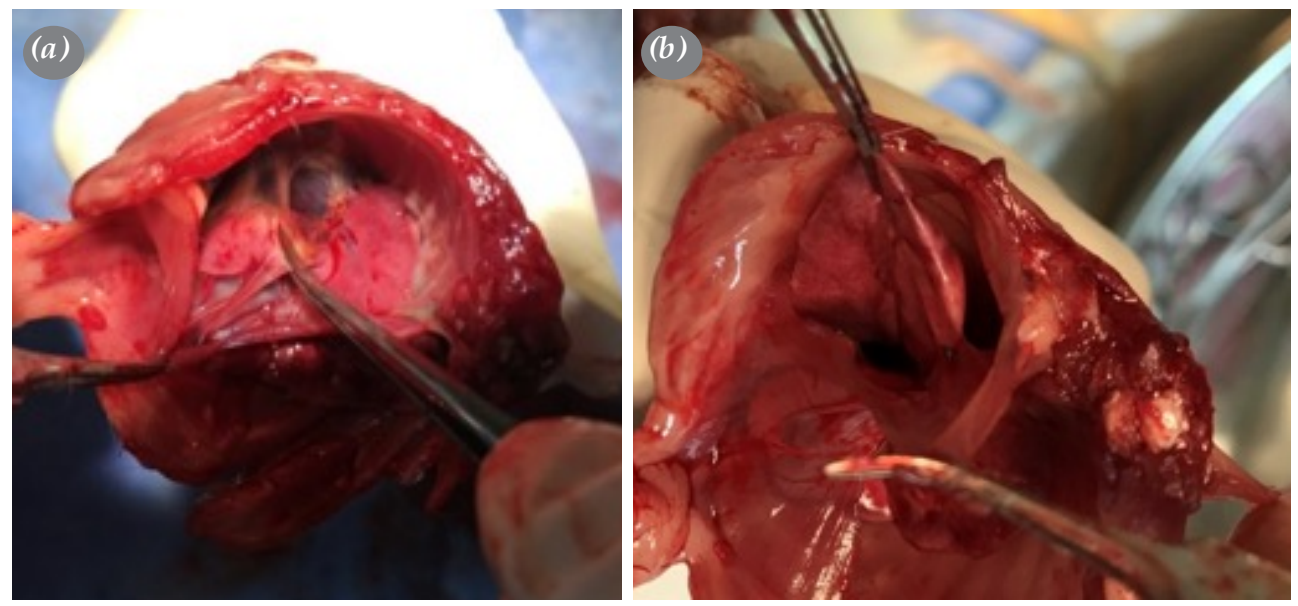

Figure 3. (a) Severe adhesions observed in the talc group, (b) severe adhesions in the $4 \%$ iodopovidone group.
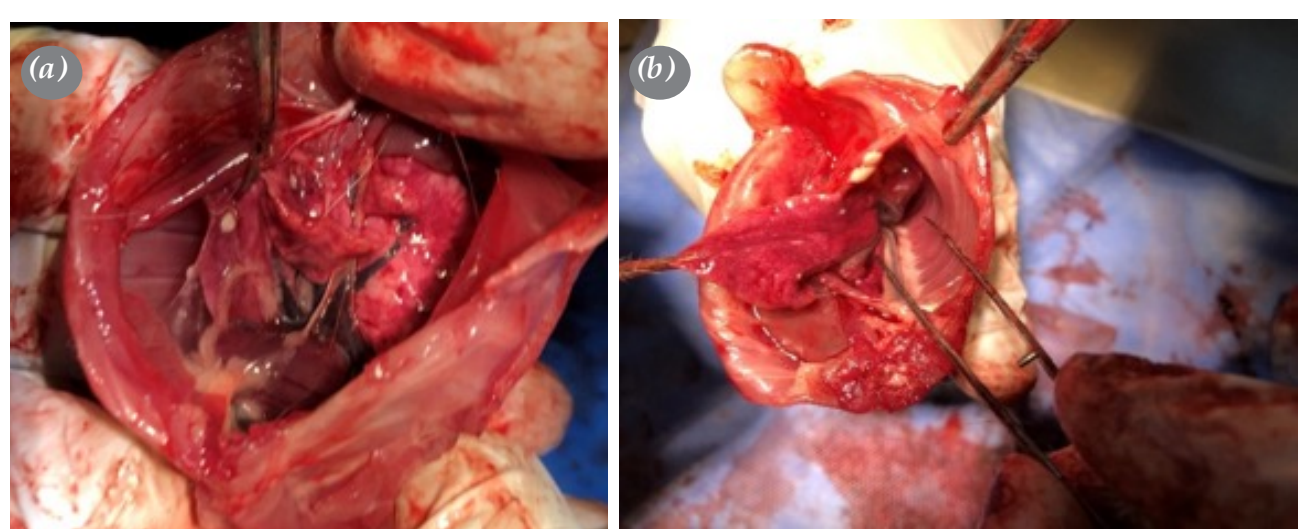

Figure 4. (a) Same side granulomas in the talc group, (b) opposite side granulomas in the talc group. 
Table 4. Binary comparisons of groups in term of alveolar collapse microscopically

\begin{tabular}{lccccc}
\hline Sample 1-sample 2 & Test statistic & SE & Standard test statistic & Significance (p) & Adjacent significance (p) \\
\hline G4K-G3 \%2 & 4,800 & 4,857 & 0.988 & 0.323 & 1,000 \\
G4K-G2 \%4 & 13,500 & 4,857 & 2,780 & 0.005 & 0.033 \\
G4K-1Talk & 21,300 & 4,857 & 4,385 & 0.001 & 0.001 \\
G3 \%2-2 \%4 & 8,700 & 4,857 & 1,791 & 0.073 & 0.440 \\
G3 \%2-G1Talk & 16,500 & 4,857 & 3,397 & 0.001 & 0.004 \\
G2 \%4-G1Talk & 7,800 & 4,857 & 1,606 & 0.108 & 0.650 \\
\hline
\end{tabular}

SE: Standard error; Each row tests the null hypothesis that the Sample 1 and Sample 2 distributions are the same asymptotic significance (2-sided tests) are displayed. The significance level is 05 .

inflammatory cell infiltration was detected in the alveolar space. In Figure 6b, there was subpleural lymphocyte dominant mononuclear inflammatory cell infiltration of the rat in the $4 \%$ iodopovidone group.

\section{Alveolar hemorrhage}

Alveolar hemorrhage scores significantly differed among the four groups $\left(\chi^{2}(3), \mathrm{p}<0.05\right)$. According to the alveolar hemorrhage factor, the differences between the G1Talc and G3 2\% and between the G1Talc and G4 C groups were statistically significant. The pairwise comparisons of the groups and the results of the auditory analysis are shown in Table 6. In Figure 7a, there was dense erythrocyte groups seen in all alveolar spaces of the rats in the talc group. Figure $7 \mathrm{~b}$ shows the focal erythrocyte deposits in the alveolar spaces of the iodopovidone group.

Table 5. Binary comparisons of groups in terms of cellular infiltrate microscopically

\begin{tabular}{lccccc}
\hline Sample 1-Sample 2 & Test statistic & SE & Standard test statistic & Significance (p) & Adjacent significance $(\mathrm{p})$ \\
\hline G4K-G3 \%2 & 3,600 & 4,547 & 0,792 & 0.429 & 1,000 \\
G4K-G2 \%4 & 5,400 & 4,547 & 1,188 & 0.235 & 1,000 \\
G4K-G1Talk & 15,800 & 4,547 & 3,475 & 0.001 & 0.003 \\
G3 \%2-G2 \%4 & 1,800 & 4,547 & 0.396 & 0.692 & 1,000 \\
G3 \%2-G1Talk & 12,200 & 4,547 & 2,683 & 0.007 & 0.044 \\
G2 \%4-G1Talk & 10,400 & 4,547 & 2,287 & 0.022 & 0.133 \\
\hline
\end{tabular}

SE: Standard error; Each row tests the null hypothesis that the Sample 1 and Sample 2 distributions are the same asymptotic significance (2-sided tests) are displayed. The significance level is 05 .
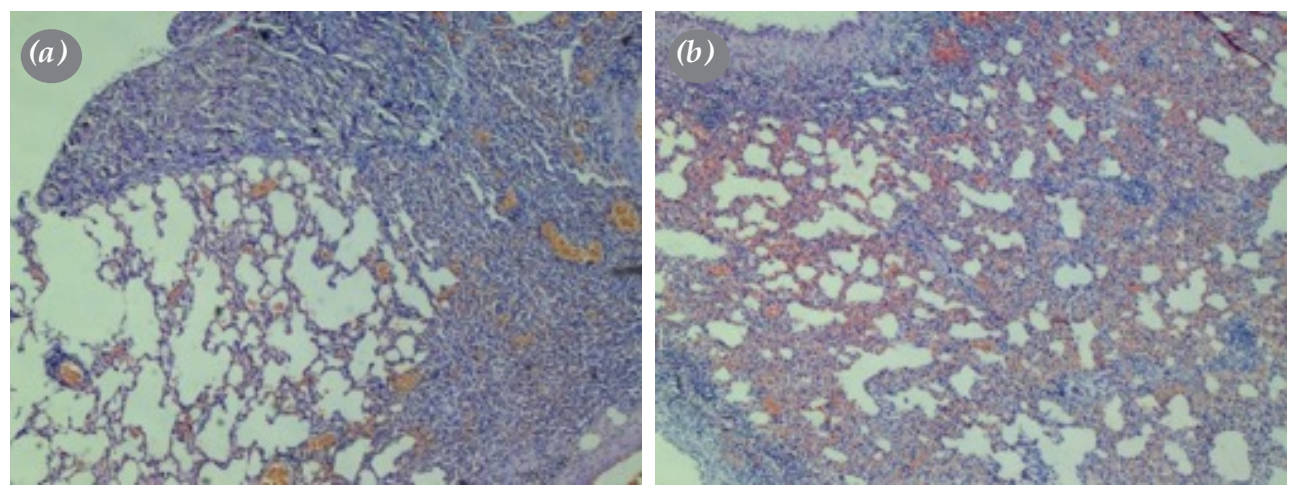

Figure 5. (a) The appearance of alveolar collapse in the talc group. It is observed that the alveolar spaces on the right side are completely closed with a solid appearance $(\mathrm{H}-\mathrm{E} \times 40)$, (b) the appearance of alveolar collapse in the $4 \%$ iodopovidone group. Alveolar collapse is more minimal compared to the talc group $(\mathrm{H}-\mathrm{E} \times 40)$. 

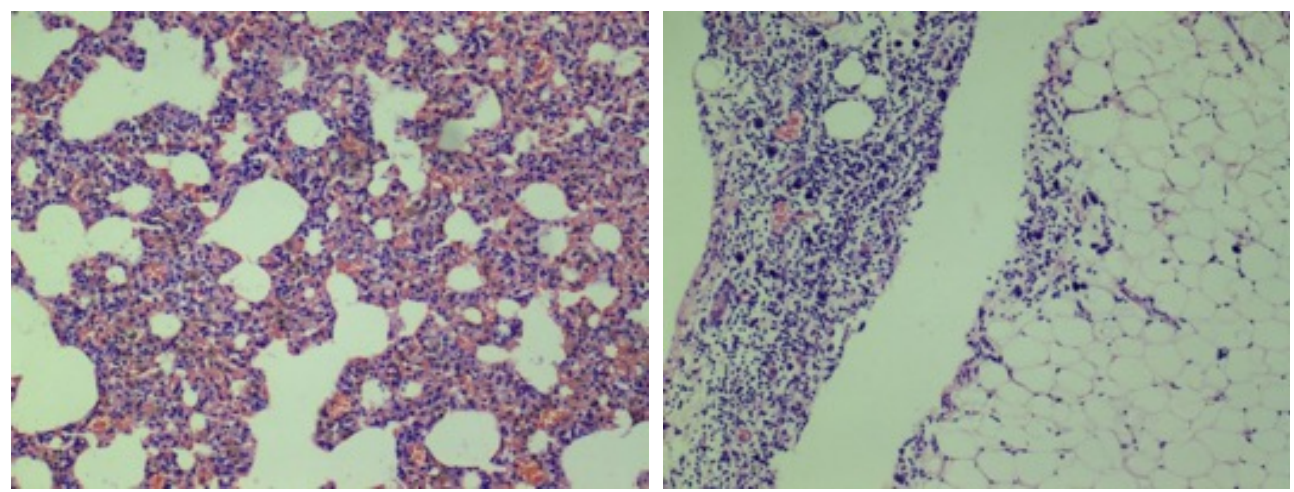

Figure 6. (a) Inflammatory cell infiltration in the talc group $(\mathrm{H}-\mathrm{E} \times 100)$, (b) subpleural lymphocyte dominant mononuclear inflammatory cell infiltration is shown in the $4 \%$ iodopovidone group $(\mathrm{H}-\mathrm{E} \times 100)$.

\section{Fibrosis}

Intrapleural adhesions and the degree of cellularity and neovascularity scores of the visceral pleura significantly differed among the four groups $\left(\chi^{2}(3), \mathrm{p}<0.05\right)$. According to the fibrosis factor, differences between G1Talc and G32\% and between G1Talc and G4K and between G2 4\% and G3 2\%, and between $\mathrm{G} 24 \%$ and G4K were statistically significant. The pairwise comparisons of the groups and the results of the auditory analysis are shown in Table 7. In Figure 8a, there was a visceral and

Table 6. Binary comparisons of groups for microscopic alveolar hemorrhage

\begin{tabular}{lccccc}
\hline Sample 1-Sample 2 & Test statistic & SE & Standard test statistic & Significance (p) & Adjacent significance (p) \\
\hline G4K-G3 \%2 & 0,850 & 4,670 & 0.182 & 0.856 & 1,000 \\
G4K-G2 \%4 & 9,600 & 4,670 & 2,056 & 0.040 & 0.239 \\
G4K-G1Talk & 14,950 & 4,670 & 3,201 & 0.001 & 0.008 \\
G3 \%2-G2 \%4 & 8,750 & 4,670 & 1,874 & 0.061 & 0.366 \\
G3 \%2-G1Talk & 14,100 & 4,670 & 3,019 & 0.003 & 0.015 \\
G2 \%4-G1Talk & 5,350 & 4,670 & 1,146 & 0.252 & 1,000
\end{tabular}

SE: Standard error; Each row tests the null hypothesis that the Sample 1 and Sample 2 distributions are the same asymptotic significance (2-sided tests) are displayed. The significance level is 05 .
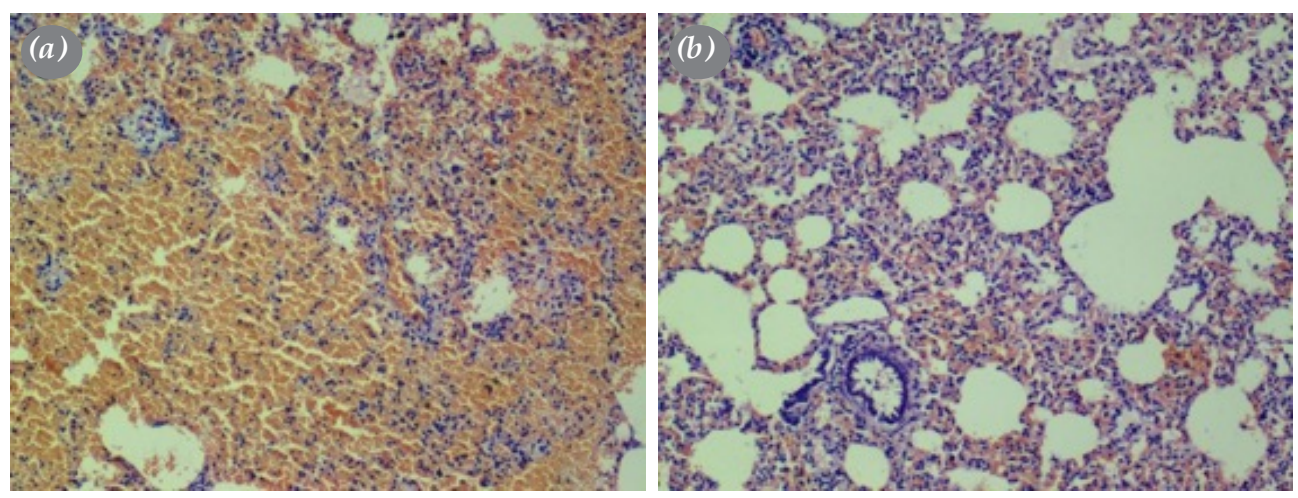

Figure 7. (a) In the talc group, dense erythrocyte groups are observed in alveolar spaces $(\mathrm{H}-\mathrm{E} \times 100)$, (b) focal erythrocyte deposits are observed in the alveolar cavities in the $4 \%$ iodopovidone group $(\mathrm{H}-\mathrm{E} \times 100)$. 
Table 7. Binary comparisons of groups in terms of fibrosis microscopically

\begin{tabular}{lccccc}
\hline Sample 1-sample 2 & Test statistic & SE & Standard test statistic & Significance (p) & Adjacent significance (p) \\
\hline G4K-G3 \%2 & 1,000 & 4,856 & 0.206 & 0.837 & 1,000 \\
G4K-G2 \%4 & 18,900 & 4,856 & 3,892 & 0.001 & 0.001 \\
G4K-G1Talk & 22,100 & 4,856 & 4,551 & 0.001 & 0.001 \\
G3 \%2-G2 \%4 & 17,900 & 4,856 & 3,686 & 0.001 & 0.001 \\
G3 \%2-G1Talk & 21,100 & 4,856 & 4,345 & 0.001 & 0.001 \\
G2 \%4-G1Talk & 3,200 & 4,856 & 0.659 & 0.510 & 1,000 \\
\hline
\end{tabular}

SE: Standard error; Each row tests the null hypothesis that the Sample 1 and Sample 2 distributions are the same asymptotic significance (2-sided tests) are displayed. The significance level is 05 .
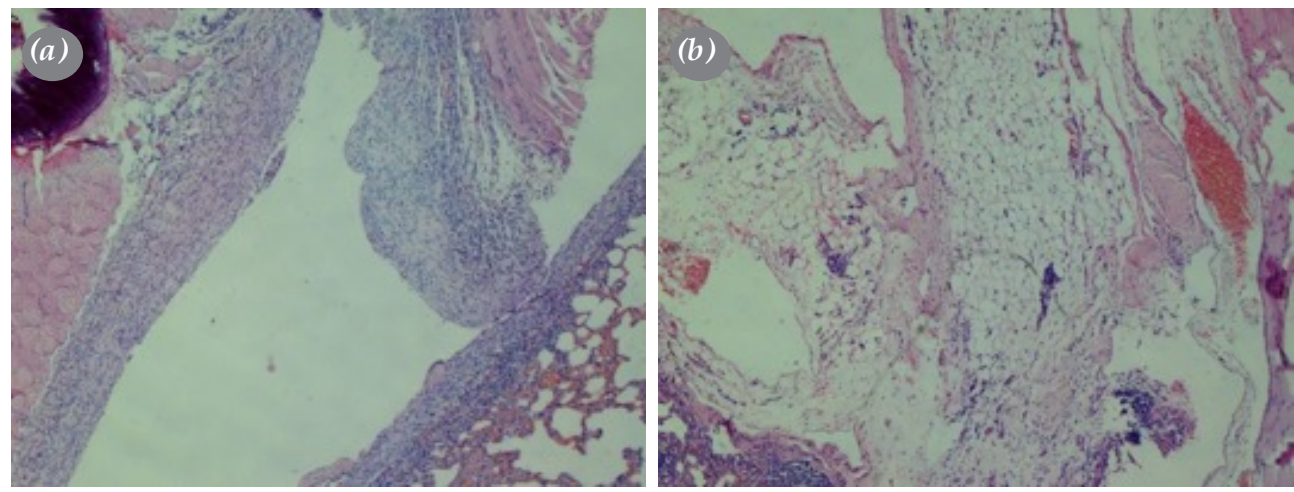

Figure 8. (a) Visceral and parietal pleurae are observed in the same frame at the talc group. It appears on the left side to break up muscle tissue by holding the parietal pleura with intense inflammation and fibrosis $(\mathrm{H}-\mathrm{E} \times 40)$, (b) in the $4 \%$ iodopovidone group, visceral and parietal pleura are observed in the same frame. Edema, vascularized and fibrotic connective tissue in the lower left corner, adjacent to the visceral pleura, is seen to be attached to the right parietal pleura $(\mathrm{H}-\mathrm{E} \times 40)$.

parietal pleura of the rat in the talc group in the same frame. Accordingly, the visceral pleura seen in the lower right side was seen to break down the muscle tissue by holding the parietal pleura (adhesion) with intense inflammation and fibrosis in the right upper corner and left side of the frame. In Figure 8b, there was a visceral and parietal pleura of the rat in the $4 \%$ iodopovidone group in the same frame. Edema and vascularized and fibrotic connective tissue were attached to the right side with the parietal pleura (adhesion) adjacent to the visceral pleura in the lower left corner.

No statistical analysis was performed for diaphragm, brain, and kidney tissues, since no granuloma and talc particles were able to be detected.

\section{DISCUSSION}

The process of adhesion of the pleural leaves and the elimination of the pleural space by creating a local inflammatory response as a result of the introduction of a sclerosing agent into the pleural space is called pleurodesis. For this purpose, over the years, several agents such as mitomycin-c, cytarabine, etoposide, fluorouracil, bleomycin and cisplatin, tetracycline and later doxycycline, minocycline, silver nitrate, Corynebacterium parvum, Streptococcus pyogenes (OK-432), autologous blood, interferons, interleukins and asbestos-free sterile talc are used..$^{[2]}$

The main expectation in the treatment is that the substance used as a pleurodesis agent is available and inexpensive with a low side effect profile and it does not extend the length of hospital stay. For this purpose, we have been using sterile talc for many years to enable it to be given in the slurry form through the chest tube or thoracoscopic insufflation, to provide faster and more effective pleurodesis than other substances. However, due to the high cost, our search for a different pleurodesis agent still continues.

In 1935, Bethune ${ }^{[3]}$ was first to describe talc as a pleurodesis agent consisting of hydrated magnesium silicate particles $(\mathrm{Mg} 3 \mathrm{Si} 4 \mathrm{O} 10(\mathrm{OH}) 2)$. The majority of particles smaller than 5 to 10 microns cause an 
excessive systemic inflammatory response with low benefits. ${ }^{[11]}$ Asbestos-free sterile talc ( 2 and $4 \mathrm{~g}$ vials) is produced by Novatech SA (La Ciotat, France) in Europe and in Turkey, with an average particle diameter of $31.3 \mu$ and free from the majority of particles below $10 \mu$. After sterile talc insufflation or slurry form delivery into the pleural space, interleukin (IL)-8 induces an intense inflammatory response in the pleural leaves by stimulating vascular endothelial growth factor (VEGF) and transforming growth factor-beta (TGF- $\beta$ ) cytokines. By stimulating IL-8, neutrophils migrating to the region induce inflammation. Through the stimulation of VEGF, capillary permeability and lymphocyte passage increase and TGF- $\beta$ initiates fibrosis by releasing profibrotic agents. ${ }^{[12]}$

The success rate of talc pleurodesis exceeds $90 \%$ in the treatment of MPE, recurrent benign pleural effusion, and recurrent secondary pneumothorax. In a retrospective study including 611 patients who underwent thoracoscopic talc pleurodesis, Steger et al. ${ }^{[5]}$ defined success as full expansion of the lung at the end of the procedure. They found the success rate of the treatment to be $68.6 \%$ and that Karnofsky Index $>50 \%$ and body mass index $<25 \mathrm{~kg} / \mathrm{m}^{2}$ were significantly associated with worse survival rates. Almind et al. ${ }^{[4]}$ compared tetracycline against sterile talc in MPE patient groups and achieved $92 \%$ success with sterile talc, while success in the tetracycline group remained at $72 \%$.

Although it seems to be the most optimal agent for pleurodesis, systemic inflammatory response and ARDS caused by systemic absorption of talc limit its use. In particular, the use of small particles in high doses may cause undesired side effects and pleural biopsy or pleural abrasion performed in the same session may lead to the passage of talc into to the systemic circulation. ${ }^{[13]}$ Olivares-Torres et al. ${ }^{[6]}$ examined pleural abrasion and talc pleurodesis and reported ARDS in $9 \%$ of patients.

The current economic conditions and social security payment policy of our country limit the accessibility and use of sterile talc. Therefore, we found it appropriate with the effect of different concentrations of povidone-iodine solution, which has a much lower cost and stated in the guidelines and is available in almost every hospital.

The use of iodopovidone solution as a pleurodesis agent was first described by Echavvaria et al. ${ }^{[14]}$ in 1991. Although the mechanism of reaction is not known exactly, it is considered to be an acidic structure $(\mathrm{pH}=2.97)$ and iodine initiates the inflammatory response of the pleural surfaces by its strong cytotoxic and oxidative effect. ${ }^{[7]}$ Agarwal et al. ${ }^{[8]}$ reported $88.5 \%$ success in patients with MPE and $93.5 \%$ in patients with pneumothorax after the use of iodopovidone as a pleurodesis agent. In terms of side effects, one study reported hypotension and visual loss; however, ARDS development and death were not been observed. ${ }^{[15]}$ In this experimental study, no morbidity was observed, consistent with the literature.

In their study, Yazkan et al. ${ }^{[16]}$ investigated the effect of iodopovidone at different doses of pleurodesis in rats and suggested that $2 \%$ concentration could be obtained to provide sufficient pleurodesis. In the present study, we found that $2 \%$ iodopovidone solution did not provide sufficient pleurodesis against sterile talc; however, $4 \%$ concentration had similar effects as sterile talc. In another study, Gözübüyük et al. ${ }^{[17]}$ investigated the side effects of oxytetracycline and talc pleurodesis in rats and observed pronounced hemorrhage and pulmonary edema in both groups in the contralateral lung parenchyma, and severe parenchymal fibrosis in the acute and subacute phases in the sterile talc group. In our study, sterile talc was found in the contralateral hemithorax, but iodopovidone had no effect on it. We believe that this would provide an advantage in patients with a low respiratory reserve who are scheduled for pleurodesis. In a clinical pleurodesis study, Andrade Neto et al. ${ }^{[18]}$ investigated the side effects and quality of life in 60 patients with $1 \%$ and $2 \%$ iodopovidone concentrations and showed that pleuritic pain was the common side effect, followed by changes in the blood pressure. Quality of life and duration of pleurodesis were comparable between the groups. Kidney failure, confusion, and loss of vision were not observed. In our study, we found no histological change due to iodopovidone in the kidney and brain. We believe that iodopovidone can be used safely, particularly in patients with comorbidities. However, further clinical studies are needed to confirm these findings.

The main limitations of this study are the lack of malignancy and inability to monitor thyroid function, blood pressure, and mental changes. A clinical study conducted by Yeginsu et al ${ }^{[19]}$ showed that iodopovidone use for pleurodesis did not have any effect on thyroid functions and could be used safely in healthy adults. However, in another study, subclinical hypothyroidism (Jod-Basedow) was shown to possibly cause thyrotoxicosis. ${ }^{[20]}$ Andrade Neto et al. ${ }^{[18]}$ also reported that five patients developed 
hypothyroidism and hormonal therapy was required for these patients. Taken together, further studies are warranted to evaluate the changes that may occur in thyroid functions.

In conclusion, our study results showed that $4 \%$ concentration of iodopovidone provided chemical pleurodesis that was similar to sterile talc in rats. We believe that iodopovidone, owing to its easy access, low cost and low side effects, can be used as a strong alternative to sterile talc.

\section{Declaration of conflicting interests}

The authors declared no conflicts of interest with respect to the authorship and/or publication of this article.

\section{Funding}

The authors received no financial support for the research and/or authorship of this article.

\section{REFERENCES}

1. Light RW. Pleural diseases. 3rd ed. Baltimore: Williams \& Wilkins; 1995.

2. Shaw P, Agarwal R. Pleurodesis for malignant pleural effusions. Cochrane Database Syst Rev 2004;(1):CD002916.

3. Bethune N.Pleural poudrage: A new technic for the deliberate production of pleural adhesion as preliminary to lobectomy. The Journal of Thoracic Surgery 1934;4:251-61.

4. Almind M, Lange P, Viskum K. Spontaneous pneumothorax: Comparison of simple drainage, talc pleurodesis, and tetracycline pleurodesis. Thorax 1989;44:627-30.

5. Steger V, Mika U, Toomes H, Walker T, Engel C, Kyriss $\mathrm{T}$, et al. Who gains most? A 10-year experience with 611 thoracoscopic talc pleurodeses. Ann Thorac Surg 2007;83:1940-5.

6. Olivares-Torres CA, Laniado-Laborín R, Chávez-García C, León-Gastelum C, Reyes-Escamilla A, Light RW. Iodopovidone pleurodesis for recurrent pleural effusions. Chest 2002;122:581-3.

7. Brissaud O, Desfrere L, Mohsen R, Fayon M, Demarquez JL. Congenital idiopathic chylothorax in neonates: Chemical pleurodesis with povidone-iodine (Betadine). Arch Dis Child Fetal Neonatal Ed 2003;88:F531-3.
8. Agarwal R, Aggarwal AN, Gupta D, Jindal SK. Efficacy and safety of iodopovidone in chemical pleurodesis: A meta-analysis of observational studies. Respir Med 2006;100:2043-7.

9. Hurewitz AN, Lidonicci K, Wu CL, Reim D, Zucker S. Histologic changes of doxycycline pleurodesis in rabbits. Effect of concentration and $\mathrm{pH}$. Chest 1994;106:1241-5.

10. Vargas FS, Antonangelo L, Capelozzi V, Vaz MA, Genofre $\mathrm{EH}$, Marchi E, et al. Lung damage in experimental pleurodesis induced by silver nitrate or talc: 1-year follow-up. Chest 2002;122:2122-6.

11. Arellano-Orden E, Romero-Falcon A, Juan JM, Ocaña Jurado M, Rodriguez-Panadero F, Montes-Worboys A. Small particle-size talc is associated with poor outcome and increased inflammation in thoracoscopic pleurodesis. Respiration 2013;86:201-9.

12. Genofre EH, Marchi E, Vargas FS. Inflammation and clinical repercussions of pleurodesis induced by intrapleural talc administration. Clinics (Sao Paulo) 2007;62:627-34.

13. Kennedy L, Rusch VW, Strange C, Ginsberg RJ, Sahn SA. Pleurodesis using talc slurry. Chest 1994;106:342-6.

14. Echavarría A, Pinzón V, Barés JP, Fernández E. Intracavitary treatment of malignant pleural effusion with iodine-povidone. Rev Med Panama 1991;16:69-74.

15. Wagenfeld L, Zeitz O, Richard G. Visual loss after povidoneiodine pleurodesis. N Engl J Med 2007;357:1264-5.

16. Yazkan R, Özpolat B, Duman L, Bircan S, Bozkurt KK, Güneş S. Identification of the concentration of iodopovidone pleurodesis in rats for the maximal effectiveness. Turk Gogus Kalp Dama 2013;21:737-42.

17. Gözübüyük A, Ozpolat B, Ciçek AF, Caylak H, Yücel O, Kavakl1 K, et al. Comparison of side effects of oxytetracycline and talc pleurodesis: An experimental study. J Cardiothorac Surg 2010;5:128.

18. Andrade Neto JD, Terra RM, Teixeira RM, Pereira SV, PegoFernandes PM. Safety profile of the use of iodopovidone for pleurodesis in patients with malignant pleural effusion. Respiration 2015;90:369-75.

19. Yeginsu A, Karamustafaoglu A, Ozugurlu F, Etikan I. Iodopovidone pleurodesis does not effect thyroid function in normal adults. Interact Cardiovasc Thorac Surg 2007;6:563-4.

20. Fradkin JE, Wolff J. Iodide-induced thyrotoxicosis. Medicine (Baltimore) 1983;62:1-20. 